\title{
Preliminary results of the initial human clinical trial of focused ultrasound to reposition kidney stones
}

\author{
Michael Bailey ${ }^{1 *}$, Barbrina Dunmire ${ }^{1}$ Bryan Cunitz ${ }^{1}$, Jonathan Harper ${ }^{1}$, Franklin Lee ${ }^{1}$, James Lingeman², \\ Mathew Sorensen ${ }^{1}$ \\ From Current and Future Applications of Focused Ultrasound 2014. 4th International Symposium \\ Washington, D.C, USA. 12-16 October 2014
}

\section{Background/introduction}

Ultrasonic propulsion is a new technology we have developed which uses focused ultrasound to transcutaneously reposition kidney stones. Two applications are expelling small stones or fragments and dislodging obstructing stones. We report preliminary, investigative findings from the first use of this technology in humans.

\section{Methods}

There are three arms of the study: de novo stones, postlithotripsy fragments, and large stones within the preoperative setting. A pain questionnaire is completed immediately prior to and following propulsion. A maximum of 40 push attempts are administered on either low $(50 \mathrm{~V})$ or high $(90 \mathrm{~V})$ power settings. Movement is classified as no motion, movement with rollback $(2-3 \mathrm{~mm})$, or movement to a new location $(>3 \mathrm{~mm}$ ) (Table 1$)$.

\section{Results and conclusions}

Eight subjects have been enrolled and undergone ultrasonic propulsion to date. None of the subjects reported pain associated with the treatment. Subjects did report a mild warming of the skin with high $(90 \mathrm{~V})$ power pushes; no sensation was reported with low $(50 \mathrm{~V})$ power pushes. A summary of push movement results is provided in Table 1. Stones were visualized and repositioned in all subjects. One subject in the post-lithotripsy arm passed two small stones immediately following treatment. At least three post-lithotripsy subjects reported passage of multiple small fragments within two weeks of treatment. In five subjects, ultrasonic propulsion identified a collection of stones previously characterized as a single stone on KUB and ultrasound. Pre-operatively, one of two $7 \mathrm{~mm}$ stones was move before surgery. In surgery, it appeared one stone was firmly attached to Randall's

Table 1. Ultrasonic Propulsion of Kidney Stones - Preliminary Results. All subjects treated with a combination of 50 V and $90 \mathrm{~V}$ output

\begin{tabular}{|c|c|c|c|c|c|c|c|}
\hline \multirow[t]{2}{*}{ Study Arm } & \multirow[t]{2}{*}{ Patient \# } & \multirow[t]{2}{*}{ Number of Stones } & \multirow[t]{2}{*}{ Stone size $(\mathrm{mm})$} & \multicolumn{3}{|c|}{ Motion Grading } & \multirow[t]{2}{*}{ Total Push Bursts } \\
\hline & & & & $2-3 \mathrm{~mm}$ & $>3 \mathrm{~mm}$ & Passed stones & \\
\hline \multirow[t]{3}{*}{ De-Novo Stones } & 1 & 3 & $2-3$ & $5(19 \%)$ & 0 & $\mathbf{N}$ & 27 \\
\hline & 2 & 5 & $2-3$ & $16(41 \%)$ & 0 & $\mathbf{N}$ & 39 \\
\hline & 3 & 2 & 3 & $1(4 \%)$ & 0 & $\mathbf{N}$ & 23 \\
\hline \multirow[t]{4}{*}{ Post-Lithotripsy } & 4 & 2 & 2 & $23(62 \%)$ & $5(13 \%)$ & $Y$ & 37 \\
\hline & 5 & 5 & $2-3$ & $21(53 \%)$ & $2(5 \%)$ & $Y$ & 40 \\
\hline & 6 & Multiple & $<2$ & $12(30 \%)$ & $4(10 \%)$ & $Y$ & 40 \\
\hline & 7 & Multiple & $2-5$ & $5(13 \%)$ & $20(50 \%)$ & unclear & 40 \\
\hline Pre-operative & 8 & 2 & 7 & $7(26 \%)$ & 0 & N/A & 27 \\
\hline
\end{tabular}

'University of Washington, Seattle, Washington, United States

Full list of author information is available at the end of the article 
plaque and the other stone had been detached from Randall's plaque and a $4 \mathrm{~mm}$ piece moved into the ureter. There have been no treatment related adverse events reported with mean follow-up of 3 months.

This is the first report of the successful repositioning of kidney stones in humans using ultrasound. Treatment was therapeutic in four subjects and provided diagnostic information in five. Subjects who did not have significant movement were the first patients and in the de novo arm. To date, there have been no reports of pain or adverse events associated with this treatment.

Acknowledgements (Funding)

Trial supported by NSBRI through NASA NCC 9-58. Research and

development supported by NIH DK043881and DK092197.

\section{Authors' details}

${ }^{1}$ University of Washington, Seattle, Washington, United States. ${ }^{2}$ Indiana

University, Indianapolis, Indiana, United States.

Published: 30 June 2015

doi:10.1186/2050-5736-3-S1-071

Cite this article as: Bailey et al:: Preliminary results of the initial human clinical trial of focused ultrasound to reposition kidney stones. Journal of Therapeutic Ultrasound 2015 3(Suppl 1):071.
Submit your next manuscript to BioMed Central and take full advantage of:

- Convenient online submission

- Thorough peer review

- No space constraints or color figure charges

- Immediate publication on acceptance

- Inclusion in PubMed, CAS, Scopus and Google Scholar

- Research which is freely available for redistribution

Submit your manuscript at www.biomedcentral.com/submit 